\title{
Genomewide DNA methylation dynamics upon diesel exhaust exposure in asthmatics
}

\author{
Ruiwei Jiang ${ }^{1 *}$, Francesco Sava ${ }^{2}$, Michael S Kobor ${ }^{3}$, Christopher R Carlsten ${ }^{2}$
}

From Canadian Society of Allergy and Clinical Immunology Annual Scientific Meeting 2013

Toronto, Canada. 3-6 October 2013

\section{Background}

Particulate air pollution can induce epigenetic changes and regulate gene expression relevant to the pathophysiology of asthma and allergic diseases. Recently, epidemiologic data suggests that there are observable acute effects of air pollution on peripheral blood DNA methylation levels of genomewide Alu and LINE-1 repeat elements, as well as certain genes involved in oxidative stress response and innate immunity. In this study, we hypothesized that in a controlled exposure setting, diesel exhaust (as a model of

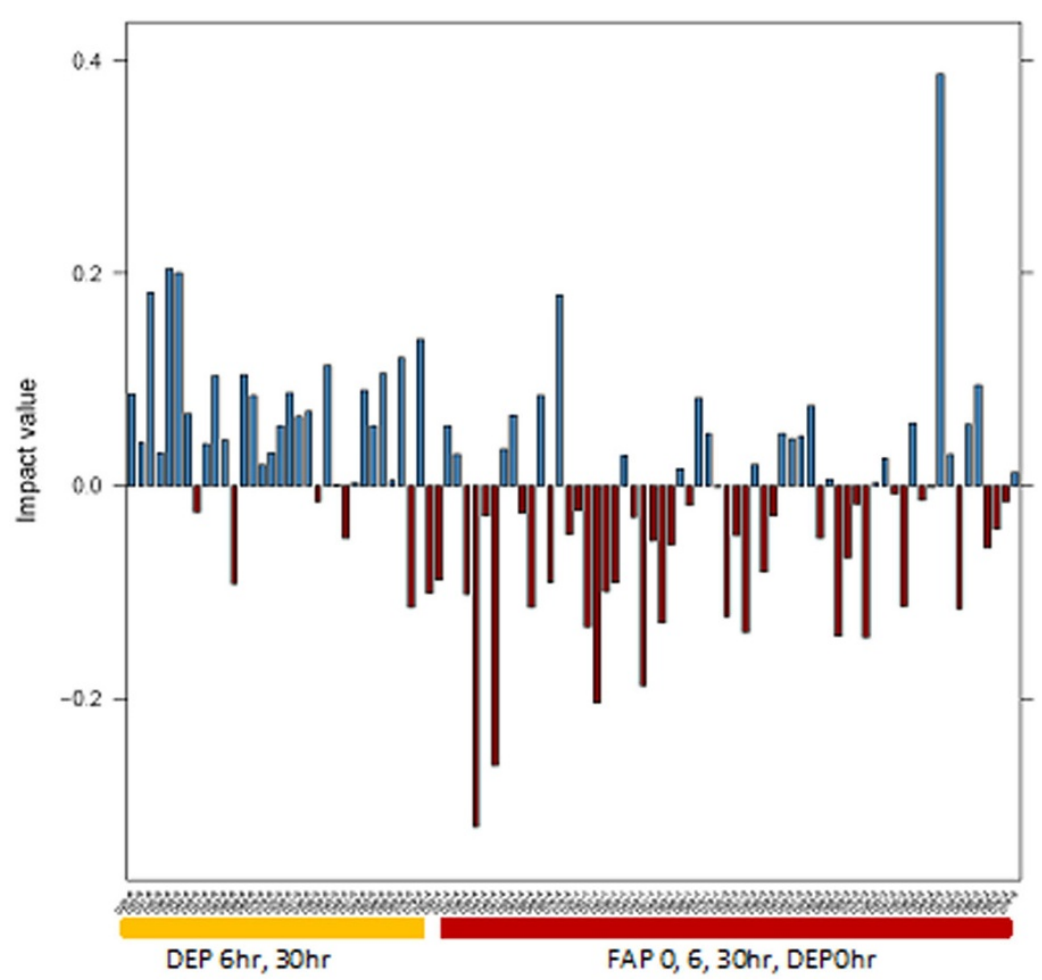

Figure 1 Impact values of each sample in principal component 22. Samples were separated into DEP 6hr and 30hr, followed by FAP 0hr, 6hr and $30 \mathrm{hr}$, and DEP Ohr.

\footnotetext{
* Correspondence: ruiwei06@gmail.com

${ }^{1}$ Genome Sciences and Technology, College for Interdisciplinary Studies,

University of British Columbia, Vancouver, British Columbia, Canada, V6T 124

Full list of author information is available at the end of the article
}

(c) 2014 Jiang et al; licensee BioMed Central Ltd. This is an Open Access article distributed under the terms of the Creative Commons 


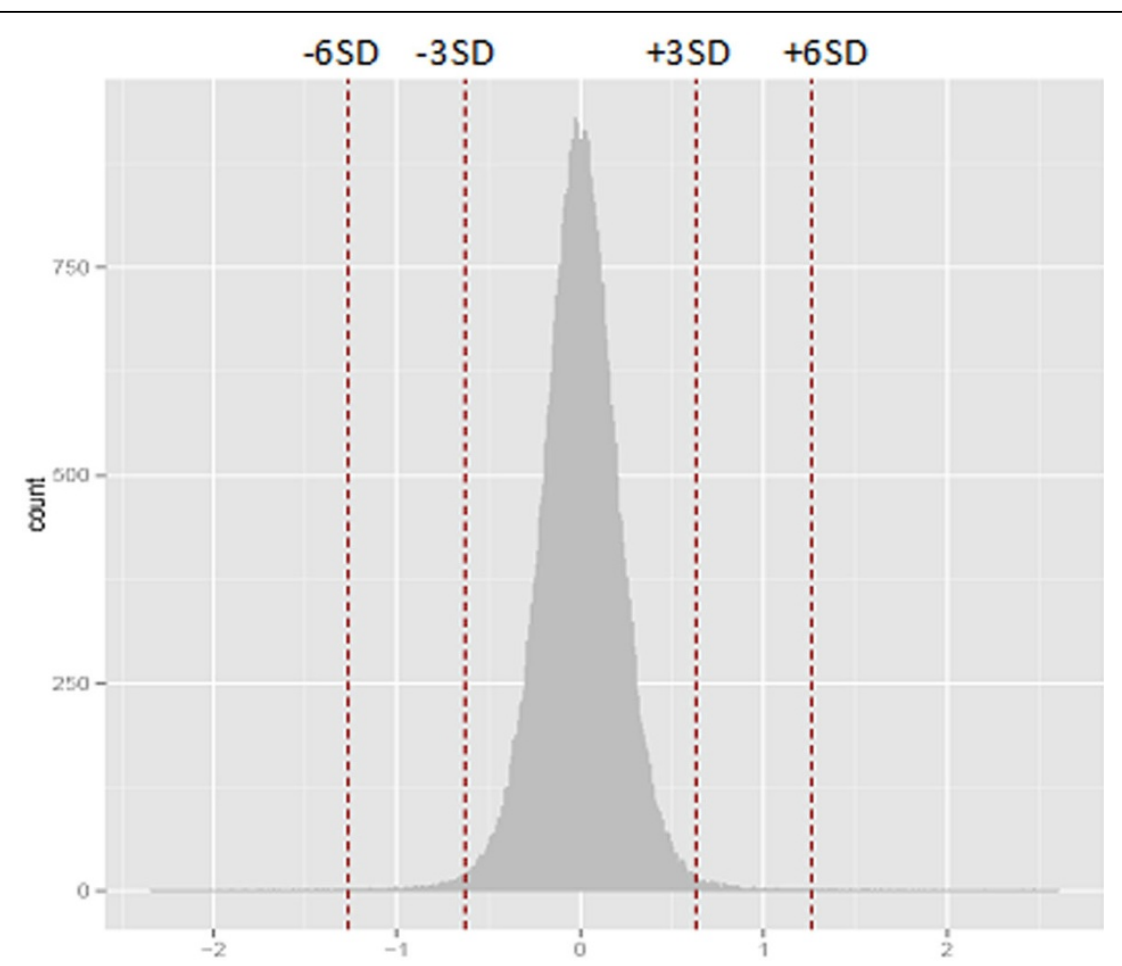

Figure 2 Distribution of probe loading values for principal component 22. The values located at \pm 3 and \pm 6 standard deviations are marked.

particulate air pollution) can induce DNA methylation changes that are detectable on the genomewide level.

\section{Methods}

We recruited 16 subjects with asthma, and/or airway hyper-responsiveness. They were exposed to both diesel exhaust (DE) and filtered air (FA) following a randomized crossover design. Peripheral blood mononuclear cells (PBMCs) were collected at baseline, 6 hours, and 30 hours post-exposure. Methylation at 415,382 CpG sites covering 39,136 genes was measured using the Illumina Infinium $450 \mathrm{~K}$ bead chip methylation array. To detect effects of the diesel exposure, we conducted a principal component analysis (PCA), resulting in principal components with common patterns of methylation variation across samples. Using this method we were able to pinpoint one principal component that was significantly associated with diesel exhaust exposure, from which we then selected a subset of probes that possessed that specific pattern of variation.

\section{Results}

Whole genome analysis using PCA followed by denoising revealed that principal component 22 , which accounted for $0.5 \%$ of the total variance, was significantly associated with the treatment variable: [DE $6 \mathrm{hr}$ and $30 \mathrm{hr}$ ] versus [DE 0hr, FA 0hr, 6hr, and 30hr] (Figure 1). Using loading cutoff of \pm 6 standard deviations, we found $89 \mathrm{CpG}$ sites to possess the specific pattern of variation (Figure 2). These include genes whose expression is associated with exposure to either diesel exhaust or components of diesel exhaust as reported by literature: CASP7, ATCAY, ABCA1, JAK3, CYFIP2, and NOX2 [1-6].

\section{Conclusions}

These results suggest that short-term exposure to diesel exhaust in a controlled setting has minimal but detectable effects on a genomewide level in PBMCs. We are currently applying mixed effects modeling and intraclass correlation to our identified hits to further substantiate the association of these hit probes to the treatment variable.

\section{Authors' details}

'Genome Sciences and Technology, College for Interdisciplinary Studies, University of British Columbia, Vancouver, British Columbia, Canada, V6T 1 Z4. ${ }^{2}$ Department of Medicine, Division of Respiratory Medicine, University of British Columbia, Vancouver, British Columbia, Canada, V5Z 1 M9.

${ }^{3}$ Department of Medical Genetics, University of British Columbia, Vancouver, British Columbia, Canada, V5Z 4H4

Published: 3 March 2014

\section{References}

1. Amara N, Bachoual R, Desmard M, Golda S, Guichard C, Lanone S, Aubier M, Ogier-Denis E, Boczkowski J: Diesel exhaust particles induce matrix metalloprotease-1 in human lung epithelial cells via a NADP(H) oxidase/ NOX4 redox-dependent mechanism. Am J Physiol Lung ell Mol Physiol 2007, 293(1):L170-181. 
2. Cao D, Tal TL, Graves LM, Gilmour I, Linak W, Reed W, Bromberg PA, Samet JM: Diesel exhaust particulate-induced activation of Stat3 requires activities of EGFR and Src in airway epithelial cells. Am J Physiol Lung Cell Mol Physiol 2007, 292(2):L422-429.

3. Hirano M, Tanaka S, Asami O: Classification of polycyclic aromatic hydrocarbons based on mutagenicity in lung tissue through DNA microarray. Environ Toxicol 2011, DOl: 10.1002/tox.20761.

4. Lee SE, Lee SH, Ryu DS, Park CS, Park KS, Park YS: Differentially-expressed genes related to atherosclerosis in acrolein-stimulated human umbilical vein endothelial cells. BioChip J 2010, 4(4):264-271.

5. Simkhovich BZ, Kleinman MT, Mehrian-Shai R, Hsu YH, Meacher D, Gookin G, Kinnon MM, Salazar K, Willet P, Feng G, Lin SM, Kloner RA: Chronic exposure to ambient particulate matter alteres cardiac gene expression patterns and markers of oxidative stress in rats. Air Qual Atmos Health 2011, 4:15-25.

6. Steiner S, Mueller L, Popovicheva OB, Raemy DO, Czerwinski J, Comte P, Mayer A, Gehr P, Rothe-Rutishauser B, Clift MJ: Cerium dioxide nanoparticles can interfere with the associated cellular mechanistic response to diesel exhaust exposure. Toxicol Lett 2012, 214(2):218-225.

doi:10.1186/1710-1492-10-S1-A67

Cite this article as: Jiang et al: Genomewide DNA methylation dynamics upon diesel exhaust exposure in asthmatics. Allergy, Asthma \& Clinical Immunology 2014 10(Suppl 1):A67.

\section{Submit your next manuscript to BioMed Central} and take full advantage of:

- Convenient online submission

- Thorough peer review

- No space constraints or color figure charges

- Immediate publication on acceptance

- Inclusion in PubMed, CAS, Scopus and Google Scholar

- Research which is freely available for redistribution

Submit your manuscript at www.biomedcentral.com/submit 